date she was in about latitude $17^{\circ}$ north, longitude $125^{\circ}$ west. The captain's wife, Mrs. Davis, described the phenomena to me as extremely brilliant.

Honolulu, Jan. 30.

S. E. Bishop.

\section{The Philadelphia biological institute.}

The proposition of Professor Allen of the University of Pennsylvania for the establishment of an institution for the education of both sexes in biological science, is one that he, and many others like minded, have long hoped to see established in Philadelphia. Indeed, it was somewhat expected, when the large building-fund that enabled the Academy of natural sciences to put up its present elegant quarters was asked for, and generously subscribed to principally by the manufacturers of Philadelphia, that something of the kind Professor Allen àsks for would be the result. The writer was principal of the school of design for women at the time the successful effort was being made for a new building for the academy; and well does he remember the promises that were then made as temptations to contributors. It may be that "the representative members of the academy" think that the quite limited extent of the "educational' plans that they have been pursuing is a fulfilment of the promises then made; and perhaps they are, as they understood it at the time. Yet do I feel quite certain, that if the gentlemen who so generously lielped the academy then, and before that time, also were told that the controlling parties of the academy were to refuse to put the building and what there is therein to the use of extended scientific education, it would be to most of them, if not to all, a surprise. I do not mean to say that the academy people have refused to do so; but it looks, from your 'Comment and criticism,' as if something of that kind had been done. My long and intimate experience with 'representative members' of public educational institutions has impressed my mind strongly with the idea that those gentlemen fail to draw distinction enough between themselves and the schools they represent; and, being placed there to manage and direct, they too often seek to carry out their own ways, rather than consider broadly the full purpose, scope, and public usefulness, of the institutions under their care, which should ever be rule, amongst evolutionists at least.

The Academy of natural sciences in Philadelphia would be a grand central body, magnificently prepared as a starting-point for biological education; and it would be a pity indeed, if the generous citizens of my old city should be put to the expense of another distinct building, and its professors to the trouble and expense of getting together another collection, perhaps to be placed within a few hundred yards or feet of the present academy. Would it not be more than a mere pity?

T. W. BRamowood.

\section{Cassiterite from King's Mountain, North Caro- lina.}

Mr. Robert Claywell, a student at the high school at King's Mountain station, on the line between Cleveland and Gaston counties, found in the street of the village a piece of mineral, which he sent me for determination. The mineral turned out to be massive cassiterite, the first found in this state. Ascertaining that there was a considerable amount of it scattered through the surface-soil there, I visited the locality, and instituted some explorations.

My expectations were more than verified when I found pieces of cassiterite from the size of an egg to the finest sand, loose and sticking in quartz, scattered over the surface in a belt beginning about the centre of the village, and extending southward a mile or more. Several shafts were sunk, and trenches dug, which finally exposed a main vein and several smaller veins of quartz and quartzite, bearing the tinstone. The veins are nearly vertical; direction of outcrop, north-east with the rocks of the country. The wallrock is a mica schist, which is broken down from both sides of the vein at places farther than has been dug. The chief accompanying minerals are tourmaline, titanic iron, mica, and, less abundant, zirkon and rutile. At points the tinstone is disseminated abundantly through the vein-rock: at other points little is found. It is mostly in small grains mingled with the other minerals, tourmaline chiefly. Changes of temperature have broken it out of the surfacerock; and washing the soil yields a black sand, which is composed of the dark-colored minerals mentioned.

The cassiterite is mostly massive or semi-crystallized. I have noticed the forms $\mathrm{P}, \mathrm{P} \infty, \infty \mathrm{P}$, and $\infty \mathrm{P} \infty$ in only a few specimens. Hardness, 6.5 to 7 ; specific gravity, 6.6 to 6.9 ; color, generally dark brown, but varying from black to almost colorless; composition, mostly an impure cassiterite, with $50 \%$ to $60 \%$ of tin, some specimens running as low as $46 \%$, others, light-colored ones, as high as $74.4 \%$. The other ingredients are silica and oxide of iron. So far, I have not detected any sulphur or arsenic.

According to Dr. Emmons, the village of King's Mountain is near the dividing-line between the Laurentian granite and the Huronian slates. To the east of the village the rocks are micaceous and slaty quartzites, talcose slates, and bluish crystalline limestone. A few miles west are the hornblende slates, gneiss, etc.

The only remark on tin which I find in writings on North Carolina mineralogy is the following from Dr. Genth ('Mineralogy of North Carolina"): "No tin ore has been found in North Carolina as yet; traces of this metal have been found in the tungstates of Cabarrus county, and in a micaceous slate (Huronian) in Gaston county, associated with garnet and columnar topaz" (the Italics and parenthesis are mine). The observation is very interesting in the light of the recent discoveries. Have we not here at King's Mountain, at or near the juncture of these slates and the older gneiss and granite, a concentration of this diffused tin?

Charles W. Dabney, jun. N.C. experiment-station, $\mathrm{Feb} 14,1884$.

\section{Behavior of Dolomedes tenebrosus.}

Last August I obtained a large female specimen of Dolomedes tenebrosus. It measured over four inches from the tips of the first pair of legs to the fourth pair. It was taken in a swamp, and confined in a tin can, where it remained a day or two before it came into my possession. Upon opening the can, I found it apparently half dead with fright. It had deposited its eggs without attempting to make a cocoon. The appearance of the eggs indicated that it had extruded them prematurely. They were mixed with an abundance of mucilaginous substance, which soon hardened, and held the eggs firmly together and fast to the can. I now put it in a cage, where it soon recovered from its fright. The cage was two by three feet, the top covered with glass, and the bottom uncovered, so that it might have the fresh earth and plants to run among.

I also put the can in the cage; but a colony of small ants (Crematogaster lineolatus) soon found the eggs, and carried them all to their own dominions. It was amusing to see them work and struggle 
to separate them from the hardened mucilage. The spider seemed to be looking at the ants, but probably did not comprehend what was going on; for it soon went to work and made a cocoon, which it carried in its mandibles. Several times I tried to take it away, but could not get it without injuring the spider. At last, after it had carried it over three weeks, I saw the cocoon lying on the ground, and supposed it had been abandoned. On pulling it to pieces, I found it composed of a cocoon and chrysalis shell of some moth, together with bits of stick, and parts of the dried flowers of the common everlasting (Gnaphalium polycephalum). While I was examining the cocoon, the spider came back to where it had left the cocoon, and appeared to be looking for it. I now put the fragments (which were partly held together by the web wound around them) near the spider, which immediately seized them with a quick, almost frantic eagerness.

The next morning it had again made quite a respectable-looking cocoon, - an irregular sort of ball, which it persevered in carrying some two months, and I do not know how much longer; as toward the latter part of October it succeeded in making its escape, and carried its precious charge away.

During all this time it took no food. I captured a number of different insects, and put them in the cage, to all of which it paid no attention. Grasshoppers recognized the spider as a foe, and at first seemed paralyzed with fear, but gradually overcame their fright, and became lively in its company. MARY Treat.

\section{ARNOLD GUYOT.}

Professor Guyot, whose death occurred at Princeton on the 8 th of February, at the age of seventy-seven, is everywhere honored for what he was, as well as for what he did. There is hardly an epithet appropriate to a good scholar, which may not be applied to him, true, wise, helpful, considerate, devout; accurate, learned, skilful in research, apt to teach, inspiring. His life was devoted to the principle laid down by Smithson for the great institution in Washington, - "the advancement and diffusion of knowledge among men." $\mathrm{He}$ was equally ready to engage in a long and tedious investigation, - such as the measurement of a group of mountain peaks, the tracing of lines of bowlders to their sources, the preparation of elaborate tables for the use of meteorologists, and the like, - or to make known in a popular lecture, or before a teachers' institute, or in the conversation of a parlor, or in a series of school-books, the results of his study. He never seemed to be thinking of himself, but always of his subject and his hearers. He cared very little for fame, very much for the study of nature and the education of man.

Like Beck, Follen, Lieber, Agassiz, and several who are still alive, he came to America after his academic training had been completed in foreign schools, and devoted himself to the service of his adopted land with an enthusiasm rarely equalled and never surpassed by the native citizen. He avoided the snare of routine which entraps so many of the college professors of this country; but, by always proposing to himself new lines of inquiry and new subjects of investigation, he kept his mind perpetually fresh, so that, until the infirmities of old age attacked him, he was younger than many of his juniors. He required no 'endowment' in order to lead him to investigation, no instructions, no commission, no salary : all he wanted was freedom. So, when vacation released him from his professor's chair, lie took to the field, and, with such comrades as were ready to join him, pursued his geographical researches.

His most original out-of-door work was performed in his own land before he came to this country, where, by a study which lasted for several summers, he succeeded in tracing to their primeval origin some thousands of erratic rocks strewn through the valleys of Switzerland. He thus rendered essential help in elucidating the problem of glacial action which his colleagues, Agassiz and Desor, were engaged in solving. Almost as remarkable was the study which he began, soon after coming to this country, of the great range of Appalachian mountains which borders the Atlantic seaboard, from Maine to Georgia. He determined barometrically the height of the principal summits in the White Mountains, then made a prolonged series of similar measurements in the Black Mountains of the south, then produced a memoir (accompanied by a map) of the entire chain, - a memoir which remains to this day the best existing description. More recently he turned his attention to the Catskills, and revealed the fact, that in this group of mountains, so near to the summer-resorts of wealth and intelligence, the highest peaks were not recorded upon the maps, and inferior peaks were regarded by the scientific visitor and the resident forester alike, as the actual summits. He knew that the problems of nature were always at hand; that careful observation and reflection would reveal some truths of interest and importance, whether the observer were placed in a new country or an old. He was one of those rare men who can ask a hard question, and proceed to answer it.

When he came to this country, in 1849 , meteorology was hardly worthy to be called a science. He foresaw what light could be thrown on the law of storms and on the variations of climate by accurate observations extended over vast areas. But he saw, also, the need of good barometrical and thermometrical 